\title{
PROCEDURAL LAW DEVELOPMENT STAGES
}

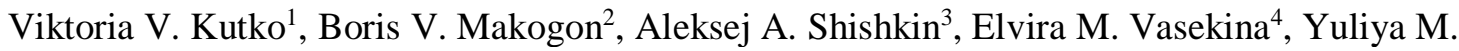 \\ Goryachkovskaya $^{5}$ \\ 1,2,4 Belgorod State University, \\ ${ }^{3}$ The Institute of service sector and entrepreneurship (branch) of DSTU in Shakhty. \\ ${ }^{5}$ Belgorod University of cooperation, Economics and law. \\ Address: 85 Pobedy Street, Belgorod, the Belgorod region, 308015, Russia
}

\begin{abstract}
The procedural legal norms play a very important role in ensuring optimal conditions for legal regulation, bear the main burden of the normative way of strengthening the rule of law, ensuring the rights, freedoms and legitimate interests of citizens. It is obvious that it is impossible to determine the trends in the procedural law development as an independent legal unit, to predict ways of optimizing and unifying certain process types in different legal families without a historical excursion. We offered various approaches to the periodization of the procedural law development, taking into account the features and the differences of legal systems.
\end{abstract}

Keywords: procedural law, development stages

\section{INTRODUCTION}

The independence and consistency of the procedural law as a legal unit is not disputed by anyone today and the legislation processualisation trend makes its felt, on the contrary. It becomes dominant not only with regard to the emergence of new types of state work and equal arrays of the procedural law norms and institutions, but is also linked to strengthening the legality requirements in the exercise of the functions of the state and its bodies, and the guarantee of implementing the rights of citizens.

Many European rights activists have repeatedly pointed out that the key factor shaping public order and public opinion is the fairness of procedural actions that are carried out by the state bodies when working with the public members [1, p. 283].

The importance of choosing the procedural means established by the relevant norms is difficult to overestimate, because "that which can be called an internal part of the procedural regime with its external component is necessary to restore an accurate picture of what happened, to ensure lawfulness, transparency and fairness of the proceedings" [2, p. 603].

It becomes obvious that it is impossible to objectively assess the real state of the legal regulation mechanism without analyzing the legal process, procedural legal norms, procedural legal relations, procedural law as a whole, since it is obvious that the democratic procedural law, mediating the interaction of the state and the individual, is a guarantor of protection of his/her rights and freedoms, an important coordination mean of the private and public interest in a society, where a person, his rights and freedoms are declared the highest value [3, p. 4].

To determine the trends and patterns of the procedural law development, it is necessary to turn to the historical way of its emergence and formation.

\section{METHODOLOGY}

We used various general scientific methods and logical cognition methods in the paper. The analysis and synthesis methods were used to study the essence of procedural law as a state-legal reality phenomenon. The historical method allowed us tracing the dynamics of procedural law and revealing the trends of its development. The system-structural approach allowed us considering the substantive and procedural as the paired components of law. The use of formal legal and comparative legal methods 
made it possible to carry out a comparative analysis of the development of procedural norms in different time periods in different legal systems.

\section{DISCUSSION AND RESULTS}

The procedural law as a set of legal norms governing the jurisdictional and other protective activities of the specially authorized bodies appeared only at the later stages of human society. The procedural law and the level of its development are a reflection of the social civilization degree [3, p. 11].

However, the very activities on legal dispute settlement (procedure) arose already at the early stages of social development.

Despite the difference in the dispute settlement procedure among different peoples and in different chronological periods of the social development, nevertheless, there are a number of its essential common features.

T.V. Kashanina distinguishes the following law development stages: a) archaic law (until the XI century); b) class or corporate law (XI-XIV centuries), c) developed or state law (XIV-XVII centuries). [4, p. 298].

The period of archaic law is characterized by casual and unsystematic nature of norms. In the early European countries, the disputes were settled by various bodies: popular assemblies, leader, and elders. The archaic law was aimed at reconciliation of the parties, so the main task was not to establish the truth and punish the guilty parties, but to eliminate the damage caused and to restore harmony in a society. The procedural law of this period is a judicial law with the practice of applying judicial duels, trials and ordeals. The archaic law was almost entirely oral and it was necessary to come up with a procedure for implementing the archaic norms so that their application did not pass unnoticed and imprinted in the memory of people. This is a kind of source of a procedural form. However, for the sake of justice, it should be noted that the peoples of this period have not known yet a precise procedure for resolving social conflicts in general.

The historical development does not always happen evenly and progressively. Legal development is not an exception. Special attention should be paid to Roman law among the systems of archaic law. The profound development of Roman private law determined the corresponding development of a civil process - "joint activities of the parties and judicial bodies aimed at dispute settlement concerning the civil rights" [5, p. 13].

There are three development periods of the Roman civil procedural law: legis action, action stricti and extraordinary.

The legis action process is the oldest process type and is characterized by the presence of legal actions lawsuits - that have been introduced and regulated by the Laws of the XII tables and have been distinguished by strict formalism. The lawsuit filing was a strict ritual, and the slightest ritual deviation from led to the loss of dispute. Thus, we can talk about the rise of the first branch of procedural law the civil procedural law.

Gradually, a large number of lawsuits led to a decrease in product turnover, the legis actions became unpopular, and the whole legis action process was replaced by the action stricti process, which was characterized by informality. The parties freely expressed their claims at that time. Then a praetor gave legal qualification to a dispute and made a brief entry at the end of in jure process - a formula that was given to a judge to make a decision.

The extraordinary process is the last stage in the Roman civil process development. Originally it emerged as an exception and then became usual and only type of civil process during the empire period, when all the power was concentrated in the hands of the emperor and the supreme bureaucracy. It has the following main features:

- a single principle of committing all procedural actions to the state officials;

- hierarchy presence in the process stages (the parties could declaim against the decisions of the lower rank officials by filing a claim to the senior officials and even the emperor himself); 
- introduction of the judicial procedure secrecy principle instead of publicity;

- cancellation of the principles of free conviction and material truth;

- process costing [3, p. 16-17].

We can state a fairly high degree of the Roman civil process development. Therefore, we can talk of the Roman civil procedural law as an independent legal phenomenon, having a specific subject and scope of regulation, different from the substantive law. Moreover, the fundamental principles of Roman civil procedural law are the basis for the procedural legislation of modern countries of the Roman-German legal family.

A special feature of the Roman procedural law development is the fact that, in comparison with the civil process, the criminal process has not been thoroughly developed and has been characterized by complete uncertainty.

Nevertheless, it is possible to identify the specifics in the development of both Roman civil and criminal procedural law. The procedural law development is determined not only by the substantive law: the reverse effect is distinctly traced in the Roman law. This is especially inherent in the criminal and action stricti civil processes, when a magistrate, while satisfying one or another claim, has protected new social relations, thus creating new norms of substantive law [6, p. 36].

In our opinion, the Roman process should be distinguished from the general periodization of the procedural law development, but we should return to further specification of the development periods of this legal unit.

As for the corporate law system, the main feature of this period is the fact that the justice as a kind of social activity has not yet completely separated from the management activities in that period. These types of activities merged often together [7, p. 194]. The judicial system did not either exist as such. The church, feudal and other courts existed on their own and did not report to each other, and there was almost no institute to appeal against court decisions.

The court sessions were informal, there were no special procedures for conducting trials. However, city law gradually began to fix and determine the summon, investigation, sentencing and execution procedures. It was introduced the need for correct and competent execution of all papers. This allows us to discover the following legal pattern: a substantive law was developed at first, and then it was developed a procedural law.

The canonical (church) law deserves special attention in this period. The humanity owes to the church justice not only because it has developed a harmonious system of courts, but also because it has made some progress in the field of procedural technique, namely:

- the justice began to be written, this meant that a civil or criminal trial could be started only with a written claim. The judgment was also written:

- there was a representation institution, which was carried out by the lawyers with a partially defined procedural status;

- the prosecution was entrusted to a special person (prosecutor);

- the purpose of the proof was to find out the truth in the case and to create conviction of the justice and sentence reasonableness in the judges.

Thus, the origin and development of a procedural form occurred in the period of corporate law $[8, \mathrm{p}$. 140].

If the corporate law still barely knew the procedural norms and estate justice was informal in nature, then the procedural norms became clearly visible at the stage of origin and development of royal law in the general array of legal norms. This is expressed in the following:

- the lawsuit forms were developed to determine offenses;

- a certain procedural unity was established;

- an investigative procedure was introduced;

- the prosecutor in criminal cases - justiciary - was introduced;

- a list of evidence taken into account in a case was been drawn up; 
- the procedural position of the judges was changed, they should occupy the "middle side", i.e. be objective and not take the position of any of the conflicting parties in advance [9, p. 186-187].

These features allow us saying that the law has received a new structure - the procedural law. The final formation and development of this legal structure falls on a developed law period, as evidenced by the following main points.

The norms of procedural law ensure the interests of an authorized party, wherefore an entire system of state structures is created.

If the procedural norms were earlier only partially included in the regulatory acts of a substantive legal nature, then the number of procedural norms has significantly increased at the developed law stage. It is true that the scope and significance of the procedural law is an indicator of the social development and civilization as a whole.

There is a specialization of the procedural regulatory acts and a codification of the procedural law. Every action of the process participants is regulated in detail in the legislation. The developed law is based on the responsibility individualization principle.

The modern development of the procedural law is characterized by a significant procedure complication. This is largely due to the fact that one of the tasks of the modern state is to take care of the individual rights. The scientific and technological progress (examination, inspection, specialist's participation in a case, using a tape recorder and other technical means for recording and reproducing evidence) significantly affected the procedural form, having caused its further complication. It can be concluded that the process development trend is the complication and differentiation of a procedural form, its focus on the all-round provision of the individual rights.

\section{CONCLUSIONS}

We conclude that the main factor that determines the visible content of procedural law is the type of legal understanding in a specific legal family. The countries of a continental legal system are characterized by the Roman law reception, the law system division into its substantive and procedural parts [10, p. 17]. Therefore, the basis for the procedural law periodization can be determined by such a criterion as the process nature, according to which it is necessary to designate legis action, action stricti, extraordinary and competitive period of the judicial procedure development.

The Anglo-Saxon legal family is characterized by the prevalence of precedent regulation, lack of division into substantive and procedural law, but this does not mean the absence of procedural rules as such.

The globalization processes, rapprochement of legal families allow us considering the law as a symbiosis of its positive and natural content. The regulatory rule and a precedent with the trend of interpenetration of common principles of the general and continental law construction is a synthesis of both ideology, the idea of law, and its dogma. Accordingly, the boundary of the procedural law is determined not only by some written procedural rules, but also by the spirit, the idea, the general principles of any procedure, which ultimately act as a norm - a legal reference point for its resolution in the situation of dispute settlement, for example [11, p. 67].

There is the following important regularity in the procedural law development: the more developed the society is, the more detailed the legislation outlines the activities related to the protection of social order, rights, freedoms and legitimate interests of citizens and organizations. It can be assumed that as the law develops as a regulator of public relations, the procedural unit will expand and improve, and its scope will be more significant in the structure of law.

\section{REFERENCES}

Tom R. Tyler. 2003. Procedural Justice, Legitimacy, and the Effective Rule of Law. Crime and Justice. Vol. 30. pp. 283-357.

Kress C. The Procedural Law of the International Criminal Court in Outline: Anatomy of a Unique Compromise. Journal of International Criminal Justice. 2003. Vol. 1. Issue 3. pp. 603-615. 
Lukyanova E.G. 2000. Procedural Law and its Place in the Structure of Law: Thesis of the Candidate of Legal Sciences. M., 218 p. (In Russian)

Kashanina T.V. 2001. The Origin of the State and Law. M., 325 p. (In Russian)

Pokrovsky I.A. 2011. The History of Roman Law. SPb., 419 p. (In Russian)

Salogubova E.V. 2014. Roman Civil Process. M., 160 p. (In Russian)

Gurevich A.Ya. 1994. Problems of the Feudalism Genesis in Western Europe. M., 396 p. (In Russian)

Burbank S.B. 1994. The Reluctant Partner: Making Procedural Law for International Civil Litigation. Law and Contemporary Problems. Vol. 57. \# 3. pp. 103-152.

Anners E.H. 1994. The History of European Law. M.: Nauka, 397 p. (In Russian)

Lenaerts K., Maselis I., Gutman K. 2014. EU Procedural Law. OUP Oxford. 1056 p.

Hill A. 1955. State Procedural Law in Federal Nondiversity Litigation. Harvard Law Review. Vol. 69. \# 1. p. 17. 